\title{
Affirmative Action: Has the Election of Barack Obama Changed the Discussion?
}

\author{
Eze Simpson Osuagwu ${ }^{1}$ \\ ${ }^{1}$ Harvard University, Extension School, Cambridge, MA 02138, United States \\ Correspondence: Eze Simpson Osuagwu, Harvard University, Extension School, 51 Brattle Street, Cambridge \\ MA 02138, United States. Email: eosuagwu@g.harvard.edu
}

Received: September 16, 2014 Accepted: October 23, 2014 Online Published: November 16, 2014

doi:10.5539/jpl.v7n4p120 URL: http://dx.doi.org/10.5539/jpl.v7n4p120

\begin{abstract}
With the election of an African American as President, many would think that the question of affirmative action and equal opportunity has been finally laid to rest in the United States. This perception may be true for the proponents of affirmative action, whom over the years believe that the struggle for civil rights and equal opportunity can only be seen to fruition if an African American emerges as President. However, the struggle to eliminate racial discrimination and social inequality cannot be achieved in one swift. It requires consistent policy directions aimed at achieving a balance in the distribution of income. This paper looks back into the origin of affirmative action; from the executive orders of President Kennedy through the decisions of the Supreme Court, and finds that matters of affirmative action have always been controversial on whether racial preferences or class distinction should be the guiding principle. The argument however, is whether the election of Barack Obama as President has reduced the agitation on racial preferences, and placed more emphasis on class distinction, as his economic and social agenda for broadening the middleclass stipulates.
\end{abstract}

Keywords: affirmative action, inequality, income distribution, middle class

\section{Introduction}

At the dawn of the election of Barack Obama as President of the United States, during his acceptance speech, notable civil rights activists and African American show business moguls were shedding tears of joy recounting the struggle over the years, albeit seeing his election as a realization of the dreams of Martin Luther King Jr. Since then, the question has been whether the election of an African American as President has completely solved the problems of affirmative action, which is rooted in the civil rights movement? The answer solely depends on which side of the argument one finds himself. Nevertheless, for the protagonists of affirmative action it is a "Yes" but; in the sense that the election has broken the racial boundary of inequality in leadership and to a large extent spurred the aspirations of an average African American. However, the struggle to eliminate racial discrimination and class inequality cannot be achieved in one swift. It requires consistent policy directions aimed at achieving a balance in the distribution of income and economic resources. In this paper, my argument rests on whether Barack Obama's domestic socio-economic policies favor affirmative action or better still, the fact that he has paid little or no attention to "affirmative action" can we infer that the focus of his economic and social policies for broadening the middleclass is rooted in his desire to empower minorities through an equitable distribution of income and opportunities.

Affirmation action in general refers to a policy of reducing discrimination or ensuring that there is perceived equal opportunity for all in federal employment and schooling. In a bid to ensure that there is equity and justice in the distribution of resources, government policies on education and employment must bridge the economic gap created by years of political and economic marginalization of minorities, but a major problem standing in the way of affirmation action is the growing number of judicial decisions in favor of reverse discrimination. The use of executive orders has been very effective in redirecting the focus on the substance of affirmative action. Perhaps in order to limit the restive implications of what the courts have to say on this matter, but the most disappointing results have come from the lack of enforcement. Indeed, scholars are of the opinion that affirmative action issues are often conceived as either a tool to combat discrimination or as a tool to redistribute jobs and earnings (Leonard 1990). The implication is that if affirmative action is aimed at eliminating discrimination, then it will be in pursuit of equal opportunity, otherwise it pursues the result. 
This paper is presented in three sections; the first section is the introduction, the second section discusses the origin and developments of affirmative action based on a review of academic literatures and presidential policy thrusts on affirmative action and third section concludes.

\section{Origin and Developments of Affirmative Action}

Affirmative action is perhaps the most controversial policy action of government since the abolition of slavery (Leonard, 1990). A major concern is whether affirmative action has succeeded in creating employment opportunities for minorities especially blacks, since Lyndon Johnson's executive order 11246 in 1965 as amended by Richard Nixon's executive order 11375 of 1974 . Although, the first major presidential policy thrust on affirmative action was the Executive order 10925 issued by President John F. Kennedy in March 1961, requiring federal contractors not to discriminate against any employee or applicant for employment based on sex, color, race, religion or national origin. Despite all the presidential executive orders on affirmative action, it has been strongly criticized as lacking the requisite teeth to knell the spate of racial discrimination on employment and schooling in American society. But, scholars equally agree that some level of success have been achieved in the number of blacks employed, not as a result of affirmative action policies, but in response to the labor demand pressure in employment opportunities. Title VII of the Civil Rights Act of 1964 is the legislation that brought into existence the Equal Employment Opportunity Commission set up by government to monitor the enforcement of complaints arising from employment discrimination against minorities. However, affirmative action has not gone down well with the white majority, who considers it a reverse discrimination in making them pay for the "deeds" of their forefathers, for instance where a qualified white student is denied admission into college to make provision for a less qualified minority student as in Grutter v. Bollinger 539 U. S. 306 (2003), a case argued in April 2003 and decided by the Supreme Court in June 2003. In this class action suit filed by white students who were denied admission to the University of Michigan's Law School, the United States Supreme Court had the opportunity to reaffirm the constitutionality of adopting affirmative action on school admissions policy. The Supreme Court found that the University of Michigan Law School admissions policy which gave certain minority students special admission consideration is not unconstitutional, and in no way violates the Fourteenth amendment of the constitution. The court found that the admission policy of the University is not to be considered a quota, which would have been unconstitutional as in the case of University of California v. Bakke 438 U.S. 265 (1978), where the University of California, Davis medical school admission policy reserved 16 seats for minority students. On the other hand, minorities are not very comfortable with seeing their earned success assumed to have been unmerited. This brings to fore the reason, why the growing number of misconceptions that arises when affirmative action issues on quotas, preferential hiring, minority education and other instances where racial considerations supersede merit, seem to lack a certain level of rational discussion.

With the election of an African American as President, many would think that the question of affirmative action and equal opportunity has been finally laid to rest in the United States. This perception may seem to be true for the proponents of affirmative action, who over the years have believed that the struggle for civil rights and equal opportunity can only be seen to fruition if an African American emerges as President. The Civil Rights movement brought issues of affirmative action to the forefront of government policy making, hence Congress enacted the Equal Opportunity Act of 1964 as the legal backbone. It is obvious that the primary purpose then was to create equal opportunities for minorities and the under-privileged in the society. However, as time went by and following subsequent interpretations of the Civil Rights Act by the courts in cases of reverse discrimination, the effect of the law on equal representation in employment, schooling and government contracting was declining. According to Robert Weiss (1997), drawing from the book We Want Jobs: A History of Affirmative Action written by Barbara Bergmann, the three basic components of affirmative action are to overcome discrimination, increase diversity in the workplace and to reduce poverty among minority groups. But in recent times the notion has changed; according to Pauwels (2011), affirmative action became a form of preferential treatment awarded to privileged groups, a form of reverse discrimination, a denial of meritocracy and social justice.

The argument against affirmative action is that it gives preferential treatment to undeserving minorities, which Goldberg (2003, pp. 56 - 57) puts succinctly "I'm against affirmative action when it means racial preferences, which in the real world is what affirmative action is usually about. Why should the children of Jesse Jackson, Colin Powell or Diana Ross get some kind of racial preference when they apply to college or go out for a job, but no 'affirmative action' is given to the child of a white Anglo-Saxon Protestant coal miner from West Virginia?" This has been the dividing line for the enforcement of affirmative action policies; whether preferential treatment should be given to a person or group based on race, gender or class in society. The protagonist of affirmative action especially those who believe that affirmative action should be seen as a form of reparation for the injustices meted upon minority racial groups especially blacks during slavery, through the Jim Crow Laws up 
until the era of legal discrimination of 'separate but equal' as espoused in Plessey v. Fergusson 163 U.S. 537 of 1896 and the subsequent reversal by the Supreme Court in Brown v. Board of Education of Topeka 347 U.S. 483 in 1954, do not consider preferential treatment to be based on class distinction. However, the opponents of affirmative action believe that there are disadvantaged individuals in all racial groups who would rather be considered for any preferential treatment, whatsoever.

The contention is that affirmative action is an instrument of social change and can only be considered effective when there is a reasonable cause to believe that it cuts across all ethnic, racial, religious and gender barriers of employment and school enrolment in public schools. This informs the reason why it has been very difficult for any presidential policy thrust to have its full weight thrown on the enforcement of the principles of affirmative action. For the enforcement of affirmation action to be effective, it must not be used as an instrument to foster discrimination against the majority, in a bid to provide opportunities for minorities. Before the emergence of affirmative action policies there have been a growing number of minorities in the middle class, so the most appropriate action for equal opportunity should be aimed at favorably enhancing the growing middle class in the society, than trying to emphasize on preferential treatment based on race, gender or religious persuasion.

As a matter of fact, minority under-representation was one of the most widely discussed issues in the polity, to the extent that President Bill Clinton in his July 19, 1995 address at the National Archives came up with a two-fold agenda on affirmative action; to restore the American dream of opportunity and value of responsibility, and to build a strong American community in the midst of diversity. As stated in Kahlenberg (1995), President Clinton's address is like the wake-up call in the recent history of affirmative action asking all Americans to brace up to the challenge to eliminate discrimination based on race, gender or social class. The President was very emphatic in his speech recounting the goal of affirmative action and how it will be achieved if Americans pursue the cause with the common purpose of inclusion, which will finally address the systemic exclusion of individuals of talent based on their gender or race from opportunities to contribute meaningful to the society. Society will suffer the attendant setback if in the long-run people of talent and skills are deprived opportunities because of their gender, race or ethnic origin.

Therefore the substance of affirmative action is to develop a systematic approach to open the doors to equal opportunities in education and employment to qualified individuals who would have been excluded in the old order. However, President Bill Clinton warned that the way out is to introduce the principle of race neutrality and the goal of aiding the disadvantaged into affirmative action preference programs; to base preferences, in education, entry level employment and public contracting, on class, not race. This was President Bill Clinton's response regarding many reverse discrimination decisions coming out of the Supreme Court in favor of the plaintiffs. In this direction, Clinton was very emphatic in his commitment towards empowering the middle class, stating that it is just wrong to believe that affirmative action caused any economic problem to the American middle class. He stated that affirmative action alone cannot solve the problems of the middle class since most minorities or women are either members of that middle class or people who are poor and are struggling to get a fair share of the American dream. Clinton suggests that the most feasible remedy to the problems of the middle class is an economic strategy that will reverse the decline in wages and poverty amongst all the working people; which includes women, minorities, and white males. President Bill Clinton's speech in 1995 and his subsequent actions while in office seem to be one of the few overtly proactive steps taken by a President in an attempt to address affirmative action issues in the past three decades.

The Bush administration however, did not improve the cause of affirmative action, he was very critical of the Supreme court's decision in Grutter v. Bollinger upholding the constitutionality of affirmative action in the admissions policy of the University of Michigan Law School. President Bush was quick to forget that he was a beneficiary of affirmative action when he was admitted to Yale University as an undergraduate and to Harvard Business School as a graduate student under the 'legacy' policies of those colleges, which gave special preference to children of alumni or well - connected members of society, reports Peter Drier - professor of politics at Occidental college in an article titled: How George W. Bush benefitted from affirmative action, posted on September 13 $3^{\text {th }}, 2014$ in his blog on Huff Post Politics. Under the administration of President George W. Bush it was a mixed bag of sometimes accepting preferences and sometimes completely opposed to racial preferences (Clegg, 2008). The question still remains, whether the cause of affirmative action has actually changed from racial preferences to class distinction following the election of Barack Obama as President?

President Barack Obama, in a speech at Osawatomie Kansas in 2011, reminded his audience about the rising inequality in the United States - a level that he considers worse than any other since the Great Depression; the inequality that strikes him most is the gap in the distribution of income. Though it is true, as observed by Kamalu and Kamalu (2004), that the ultimate goal of the Civil Rights movement and the struggle for equal opportunity is 
to see an African American emerge as President, the implementation of affirmative action goes beyond the interest of the President. Pauwels (2011) observes that since an African American has been elected President, the future of affirmative action is uncertain and the discussion has been removed from the public domain. Pauwels observation may be true for those who believe that racial equality is the ultimate goal of affirmative action. But, beyond the racial factor is the disparity in social status that results from the lack of economic opportunities for minorities. Though, the election of Barack Obama has bridged the racial gap, but class distinction remains an issue for discourse. President Obama's struggle for the restoration of the middle class may be proactive, but suggests that he is conscious that the inequality in the society emanates from the class structure rather than in the racial perspective, this concurs with Bill Clinton's remarks about inequality arising from the uneven distribution of opportunities to foster the American dream. However, in the light of the observations in Pauwel and Kahlenberg, also in the views of the proponents of affirmative action, the election of Barack Obama as President has removed the discussion from the public domain; because all those who consider affirmative action as the clamor for equal opportunity in political leadership have been stunned, and made speechless. Little wonder, political satirist claim that the likes of Reverend Jesse Jackson have been rendered "jobless" by the outcome of the election. But, alas the President is not unmindful of the fact that the task ahead is enormous and should be fought to please all the stakeholders, to this end he has refrained from acts that will portray him as an "African American" president rather than the President of the United States he was elected to serve. In a bid to maintain the posture of the later, the President has kept mute on issues of affirmative action and unlike his predecessors has the least incidence of discussions on this burning issue. In the main, it would be right to say that following the election of Barack Obama as the President of the United States the discussion on affirmative action has been removed from the public domain to a perspective that is most expedient and conforms to the President's economic agenda.

The economic emancipation of minority groups should be the driving force of any legislation or government policy aimed at providing equal opportunity in the society. President Barack Obama reiterates in his speech in 2011 that "when middle-class families can no longer afford to buy the goods and services that businesses are selling, when people are slipping out of the middle class, it drags down the entire economy from top to bottom." The important issue here is that the middle class cuts across racial boundaries, hence the economic emancipation of the middle class takes the discussion of affirmation action to the public domain of the entire American society.

As Barack Obama emerged President of the United States, protagonists of civil rights and equal opportunity would have thought that he will be the champion of affirmative action, being of the minority stock himself. Nevertheless, he has redirected the discussion to suit the burning issue of his economic policy - the economy and distribution of income. Surprisingly, they would say that Barack Obama has not elevated the discussion of affirmative action to the height and enthusiasm it was taken to by Bill Clinton, who in his speech to congress in 1995 was emphatic as to the way forward stating "today I am directing all our agencies to comply with the Supreme Court's Adarand decision, and also to apply the four standards of fairness to all our affirmative action programs that I have already articulated: no quotas in theory or practice, no illegal discrimination of any kind, including reverse discrimination; no preference for people who are not qualified for any job or other opportunity ; and as soon as a program has succeeded, it must be retired. Any program that doesn't meet these four principles must be eliminated or reformed to meet them." In Adarand Contractors Inc. v. Federico Pena, Secretary of Transport et al.515 U.S. 200 (1995), a highway construction contract was awarded to Mountain Gravel and Construction Company, who sub-contracted to Gonzalez Construction, the company with a higher bid, because the Small Business Administration had certified that the company is disadvantaged. Adarand filed a suit against the Department of Transportation challenging the sub-contract clause under which the contract was awarded to a higher bid instead of the lowest. The Supreme Court held the subcontract clause to be unconstitutional because it violates the equal protection clause of the $14^{\text {th }}$ Amendment as well as the due process clause of the $5^{\text {th }}$ Amendment. The court further warned that all racial classifications imposed by all agencies of government should apply "strict scrutiny" as opposed to the narrowly construed standard of "intermediate scrutiny" applied in the case of Metropolitan Broadcasting, Inc. v. FCC 497 U.S. 547 (1990). President Bill Clinton was very astute and never minced words in his desire to pursue the tenets of affirmative action to a logical conclusion during his tenure.

Proponents of affirmative action have posited that a major step in guaranteeing affirmative action is by winning the political war as well, by electing friends of affirmative action to the presidency, state courts, and top judicial positions and the election of judges who are "judicial activists" to the bench to continue to uphold the constitution to meet the needs of contemporary American society (Kamalu \& Kamalu 2004). This position may not always hold sway as we can see from the present circumstances that even those perceived to be friends of 
affirmative action may not be seen to further the cause so generously. Meanwhile, the emergence of an affluent black middle class also made affirmative action claims seem increasingly suspicious, climaxing with President Barack Obama's election, dubbed by some the 'death knell' of affirmative action (Magliocca, 2008). African Americans are now gradually coming to terms that the wings of racial discrimination have been broken, and to a large extent turned to the annals of history with the election of Barack Obama as President.

If the racial content of equal opportunity is undermined, as can be seen in the decisions of courts, then it is obvious that what is left in the legislation will not be for the benefit of minorities only, but for the underprivileged class in the society. To many Americans, affirmative action has now become irrelevant, a concept only debated in narrow academic circles that cling to the outdated idea of institutionalized racism (Young, 2009). Apparently, affirmative action programs have been reformulated to avoid polarization, they don't focus overtly on race and ethnicity, they cast the net wide so as to seem all-inclusive and they are backed up by strong court cases and judicial decisions in favor of reverse discrimination, and strong opposition for racial preferences.

Opponents of affirmative action have often advanced the views that the fundamental principles of capitalism and the market economy do not provide for absolute equality, it would be utopian for anyone to wish that there will be equality in the distribution of resources. Nevertheless, the struggle for equality that is rooted in the civil rights movement was informed by outright racism and economic deprivation designed through policies of government that were inherently exclusive at the time. It is this struggle for equality that is manifest in the consciousness of the people especially for African Americans to see the election of Barack Obama as a relief for this long struggle for racial equality and economic emancipation.

The struggle for racial equality ultimately goes with so many expectations, which practically includes getting one from the minority stock into highest position of governmental decision making. The election of Barack Obama obviously came to fill a very wide gap, civil rights activists had to heave a sigh of relief and it became a turning point in the annals of American history. It obviously turned out good, and it seems everyone has rested his case and the expectation is now focused on the results of the performance of the President in regards to elevating the economic status of average African American. A wild expectation one would say, but immediately after the general election in November 2008, according to Pauwels (2011) a New York Times/CBS poll found that the proportion of people who believe blacks "have an equal chance of getting ahead" had risen to 64 per cent, up from 46 per cent in 1997.

Some scholars have been very critical of race based affirmative action, Clegg (2008) argue that pursuing the cause of affirmative action will undermine the fundamental principles of free enterprise and the spirit of hard work that accompanies economic independence. He went further to state that "the American dream has always been that any American can work toward the life he or she wants, and will have the opportunity and the freedom to achieve and accomplish what he or she wants in life. There will be hurdles to overcome, but one barrier that should not be there is the color of an American's skin or where an American's ancestors came from," however, we all know that for many years - for centuries - that dream was not allowed to many Americans.

Too often, discrimination because of race or ethnicity denied Americans the equality of opportunity they should have had. President Bill Clinton in 1995 restated the fundamental principles of affirmative action that "the purpose is to give our nation a way to finally address the systemic exclusion of individuals of talent on the basis of their gender or race from opportunities to develop, perform, achieve and contribute". Affirmative action is an effort to develop a systematic approach to open the doors of education, employment and business development opportunities to qualified individuals who happen to be members of groups that have experienced longstanding and persistent discrimination.

Nevertheless, the Obama administration has recognized equality from the perspective of the distribution of resources and opportunities. Like he said in Kansas, "America was built on the idea of broad-based prosperity, of strong consumers all across the country. That's why a CEO like Henry Ford made it his mission to pay his workers enough so that they could buy the cars he made. It's also why a recent study showed that countries with less inequality tend to have stronger and steadier economic growth over the long run. Inequality also distorts our democracy. It gives an outsized voice to the few who can afford high-priced lobbyists and unlimited campaign contributions, and it runs the risk of selling out our democracy to the highest bidder. It leaves everyone else rightly suspicious that the system in Washington is rigged against them that our elected representatives aren't looking out for the interests of most Americans", this sounds like substantiating an argument for the sustenance of the middle class in America, knowing full well that empowering the middle class will drive the economy through increased consumption and productivity and ultimately economic growth. 
What is more intriguing about the arguments of affirmative action is that there is a shift of the premise due to several reasons: affirmative action was supposedly temporary and targeted at black community only; in fact, these measures were extended over the years to an increasing number of new categories; women (who are today acknowledged as being the prime beneficiaries), then most other ethnic minority groups, including new immigrants (Pauwels, 2011). Its primary rationale became blurred in 1978 when the Bakke decision shifted the goal of affirmative action from repairing past injustices against the black community to the much more ambitious and less clearly defined justification of achieving diversity (Frymer \& Skrentny, 2004). Even President Bill Clinton realized this shift in his 1995 speech to congress when he said "that affirmative action has not always been perfect, and affirmative action should not go on forever. It should be changed now to take care of those things that are wrong, and it should be retired when its job is done. I am resolved that that day will come, but the evidence suggests indeed that that day has not come". However, that day finally came with the election of an African American as the President of United States, whose drive is no longer affirmative action but equality in income distribution and the provision of basic opportunities for the benefit of all and sundry especially creating a formidable middle class that will cut across all racial and ethnic origins.

\section{Conclusion}

Affirmative action stem from the desire of minorities to seek equal opportunities in the polity, which spans through civil rights movements and Civil Rights legislations passed to cushion the effects of slavery and discrimination meted on minorities especially African Americans. The struggle for economic freedom and the match to political equality have never been conceived to be closer to success anytime in history than it was at the dawn of November $4^{\text {th }} 2008$; when Barack Obama was first elected President of the United States. The general conception is that affirmative action has been finally laid to rest following the election of the first African American president, but alas, many protagonists would agree that the cause of affirmative action only changed from racial preferences to class distinction.

Since the decisions of courts seem to undermine the racial content of equal opportunity, it is obvious that what is left of affirmative action will not be for the benefits of minorities only, but for the underprivileged class in the society. This informs the reason why President Barack Obama has kept his focus on the economic and social emancipation of the middleclass as a unit. The politics behind this line of thought is not within the scope of this essay. However, it is obvious that as a person of African American descent, President Barack Obama needs to keep the discussion of affirmative action flowing. Albeit, the discussion has to take a new dimension, which is redirected to a more pro-active, result oriented, but non-discriminative stance such as the cause of the middle class.

This paper did not argue on the merits and demerits of affirmative action policies or its enforcement challenges. The primary concern here is to show how President Barack Obama has tried to overtly stay away from the controversies of affirmative action, but at the same time tacitly inclined to fighting the cause through his economic and social policies as it affects the middle class. Unlike the presidents before Barack Obama who have issued executive orders and verbally expressed their disaffection to matters concerning affirmative action, he has convincingly refrained from any direct policy statement on this issue.

\section{References}

Clegg, R. (2008). Unfinished Business: The Bush Administration and Racial Preferences. Harvard Journal of Law, Public Policy, 32, 971-997.

Clinton, B. (1995). Remarks by the President on Affirmative Action, Essential Speeches 2009. Academic Search Premier.

Frymer, P., \& Skrentny, J. D. (2004). The rise of instrumental affirmative action: Law and the new significance of race in America. Connecticut law review, 36(3), 677-723.

Goldberg, B. (2003). Bias: A CBS insider exposes how the media distort the news. New York, Harper Collins.

Kahlenberg, R. (1995, April 3). Class Not - Race: An Affirmative Action that works. The New Republic.

Kamalu, J., \& Kamalu, N. (2004). From Bakke to Grutter: The Supreme Court and the Struggle over Affirmative Action in the Era of Globalization. The Western Journal of Black Studies, 28(4), 489-502.

Leonard, J. S. (1990, Fall). The impact of Affirmative Action Regulation and Equal Employment Law on Black Employment. Journal of Economic Perspectives, 4(4), 47-63. http://dx.doi.org/10.1257/jep.4.4.47

Magliocca, G. N. (2008). The Obama realignment (and what comes next). Working Paper. Retrieved from http://ssrn.com/abstract_1310202 
Obama, B. (2011). The New Nationalism: On the whole and in the long run we shall go up or down together. President of the United States: Speech delivered at Osawatomie High School, Osawatomie, Kansas December 6.

Pauwels, M.-C. (2011). Does Affirmative Action have a Future in Barack Obama's America? Journal of Intercultural Studies, 32(3), 309-319. http://dx.doi.org/10.1080/07256868.2011.565740

Weiss, R. J. (1997). We Want Jobs: A History of Affirmative Action. New York, Garland.

Young, C. (2009). Obama: Race and Affirmative Action. Real clear politics. Retrieved from http:/www.realclearpolitics.com/articles/2009/01/dnp_obama_race_and_affirmative.html

\section{Copyrights}

Copyright for this article is retained by the author(s), with first publication rights granted to the journal.

This is an open-access article distributed under the terms and conditions of the Creative Commons Attribution license (http://creativecommons.org/licenses/by/3.0/). 